\title{
寺野寿郎先生とファジイ研究事始
}

日本知能情報ファジィ学会会長

\section{福田 敏男}

寺野寿郎先生のご逝去に当たり、ご冥福をお祈りい たします。寺野先生は日本のファジイ理論のパイオニ アであり、ファジィ理論とその応用の研究と普及を精 力的に名実ともに進められました。また、本学会日本 ファジィ学会の創始者であり、本会の名誉会崱であら れました。

私が1975年エール大学から 2 年間の留学を終え大学 研究室に戻って来たとき、当時の私の指導教官である 恩師の東京大学生産技術研究所柴田碧先生がこんな面 白いものがあるぞといって教えていただいたのが、ファ ジィ理論であった。留学時代はエール大学ナレンドラ 教授の元で、リヤプノフの方法による適応制御理論の 方法を勉強してきた。しかし、研究室では原文雄先生 (現東京理科大学) や出沢正德先生 (現電気通信大学) らを顧問として早速、このファジィ理論について水本 先生（大阪電気通信大学）の数理科学連載講義を基に

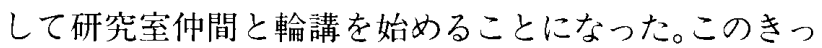
かけを作っていただいたのも恩師の柴田先生のおかげ である。

当時東京工業大学の寺野先生のグループが先生の助 手をしておられた菅野先生や㙇本先生（現名城大学） をはじめ精力的にファジィ積分やファジィ逆関数とそ の忍用の研究を進めておられました。柴田先生と寺野 先生が相談され、東大と東工大とで交互の研究会を開 かれることになりました。ともに懐の広い先生方だっ たのでこの話は一言で決まったと聞きました。おかげ で、東工大のグループの先生方とこれを契機に知り合 いになることができました。東工大での研究会の後は、 いつも決まって寺野先生の研究室でウイスキーのロッ クグラスを傾け、氷とグラスの音を聞きながら、話題 豊䈏な寺野先生の話に耳を傾けました。先生がこの音 を聞かないとよい発想が出てこないよと目を細めてに こやかに話しておられたのが今でも目に浮かびます。 この研究会で、当時東厂大飯島研究室で画像処理・パ ターン認識研究をしていた廣田先生にもお会いするこ とになりました。この研究会で毎年、報告書が作られ ました。話題は、ファジィ理論だけでなく官能検查、 法律問題など工学系から経営・文系まで幅広いもので した。これも寺野先生たちの先見性と度量の大きさの おかげでした。後に、ブルーバックス本を出版された りして、ファジィ理論とその応用の普及に貢献されま
した。感服したのは、他の制御理論研究者の人たちか らのファジィ理論なんてといった批判にまったく耳を 貸さず、びくともせず、研究者に勇気を与え研究を進 められたことです。その後、ファジィ理論の興隆と各 種応用のすばらしい成功を収められたのは周知の通り です。先生はファジィ理論だけでなく、マシンインター フェースなどの応用にもいろいろ興味を示されました。 先生たちとバークレイに行ったときも、ザデー教授を 心安く紹介していただき、その後の交流を深める基と なりました。

恩師の柴田先生が日本機械学会でたくさんの企業を 勧誘して研究協力部令を始如れたときも、寺野先生 がファジィと人間関係について研究班をまとめられ、 その後、寺野先生が柴田先生の後、研究協力部会をま とめられました。当時、大学の研究費はあまりなく、 この研究協力部会からの研究費は私にとって大変貴重 なものでした。

日本でファジィの国際会議をするとのことで、寺野 先生が委員長として学習院大学で国際ファジィ会議

(IFSA)が行われるとのことで東工大にはせ参じまし な。幅広い分野をファジィでまとめられたものでした。 先生のお人柄で、大成功するのも当たり前でした。そ の後、地中海のスペイン領のマジョルカ島でIFSA の 国際会議があった時、先生と廣田先生、私の 3 人で旅 行をさせていただきました。マジョルカ島はヨーロッ パでも有名なリゾート地であったので、ドイッやイギ リス、フランス等のヨーロッパの人たちで国際色に満 ちていました。夏でもあるのでマジョル力島では先生 と一緒に会議に参加するほか、きれいなビーチに行き 海水浴だけでなく、すばらしい地中海の景色など目の 保養をしてきました。また、その後、ホテルの予約も せず 3 人で首都マドリッドに行き、3人部屋の安宿に 泊まって、フラメンコショウや闘牛を見て来ました。 気さくな先生な゙からできることでしょうが、会議に行 きながら、いろいろな人と交流するすべといかに人生 を楽しむかといったことを先生から教えていただきま した。このようなことは、なかなか口や文書で教えて いただけるものではなく、そばにいてなんとなくファ ジィに会得するものです。

先生は東工大、法政大学と研究・教育にいそしまれ、 ファジィ分野でたくさんのすばらしい人を輩出されま 
した。おかげで人の輪がいつも広がりました。横浜に LIFEの研究所を設让されたときも、研究員に呼んでい ただき、黄畞先生ともども、楽しくさせていただきま した。何しろ、厳しい研究打ち合わせの後は、横浜の 小華街を初めとして、横浜では食事どころに困りませ ん。夜遅くまで、いろいろお世話になりました。外国 の研究員も積嫩的に呼ばれ、そのおかげで、今でも当 時の外国研究真の先生方と仲良くさせていただいてい ます。日本ファジィ学会も LIFEのサポートで設站され ました。1995年には横浜パスフィコでIEEEと合问で国 際会議が菅野先生を委員長として開催されました。廣
四先止と私がプログラム共同委員長として仩事をさせ ていただきました。これも LIFEのサポートがあってで きたものです。

以上のように、まさに、先生は日本のファジィ理論 の創始者だけでなくその恶及にご尽力されました。ま た、研究の先見性と性格の度量の広さもあり、つ敉に 日本のファジィ研究者のアトラクターとなって、研究 者が仲良く一丸となって研究を進める環境を作られま した。先生の偉大さをしのぶとともに先生のご冥福を お祈りいたします。

\title{
ファジィ研究の功労者寺野寿郎先生を偲んで
}

\author{
大阪府立大学名誉教授
}

\section{浅居 喜代治}

このたび、ファジィ研究で終始ご指導・ご鞭撻を頂 き、またこの研究の推進に行動を共にさせて頂いた寺 野先坐:がご逝去との知らせに接し、驚いています。ご 遺族初めご関係の皆さんに、心からお悔やみ中し上げ ますと共に、先生の瑟の葄からんことを打祈り致しま す。

振り这りますと、私が、1967年から68年にかけてカ リフォルニヤ大学バークレィ校に留学し、L. A. Zadeh 先生からファジィ理論を学んで事国し、ごく初歩的な ファジィ・オートマトンによる骂㥜に関する論文や、 ファジィの P R 記事を兴会誌などに発表しましたとこ ろ、早速、寺野先生からご連絡があり、これから関東 で研究会を発㘳させるので、協少方のご依賴がありま した。これがきっかけとなって、関西にもファジィの 研究会ができました。これら両研究会が中心となり、 現在导発展しつつあるファジィシテムシンポジュウム の発足や、家電を中心とするファジィブームの到来を 招きました。封野先生は、更に、門下生の菅野道夫先 生と共に、国際ファジィシステム單会の発足に尽力さ れ、その会長として活躍されました。その支部が、各 国・各地域に作られ、日本支部もできましたが、これ が、後に日本ファジィ学会となり、更に現在の日本知 能情報ファジィ学会と発展しました。寺野先生は、こ のようにオーガナイザーとして、また実行㞦優れた 方でしたが、さらに、菅野先生と共に、当時の通商産 業省によるファジイ工学研究所の設立に努力され、7 年間にわたって所長として産業界の発展に尽くされま した。日本の多くの企業の中堅技術者が、ここで研究 を行い、優れた成果を挙げると共に、ファジィ理論と
忍用の技術を身につけ、各企業の技術力となり、その 発展に大きく貢献しました。ここでは、他の大学・企 業・研究所などとの共同研究が行われ、海外の研究考 己参加されて活気に満ちていました。ご命息の隆雄さ んも参加されていて、私どもは、立派な後継者を学て られ、先生が大変憘びになっていられることとお祭 ししています。私どもも共闹研究などでなびたび訪れ、 寺野先生のおおらかな、そうして的確な教えを頂くの を楽しみにしていました。

寺野先牛は、お酒を好まれ、私は菅野先牛と共に、 よくお席を问じくさせて頂きました。先生の稳やかな 語り口は、扮酒と共にますます滑らかになり、先牲の 大きい風格をしみじみと感じました。は記の、ファジィ 研究の発展の方策やファジィ学会の設立の構想など、 又はファジィの啓蒙書の出版に至るまで多くの発想は、 ここで生まれたものと思います。

またこの分野は、国際会議が多いのですが、研究発 表・総会・想親会や各地での観光など、先生とご一緒 した思い出は多く、すべてに先牛の暖かい思いやりを 感じました。

先生とは、ご一緒にファジイの研究を始め、その発 展に努め、国際学会や日本ファジィ学会の名誉会員に 推举され、その後も常に交流を続けていましたが、こ こにお別れのときが訪れ、媣い淋しさを感じておりま के。

先生、別の世界から、今まで同様に私どもを導き、 励ましてトさい。

先生の霊の平妄と、ご遺族のご多幸を祈りつつ

追悼まで 